Selcuk Journal of Agriculture and Food Sciences

http://sjafs.selcuk.edu.tr/sjafs/index

Research Article
SJAFS

(2019) $33(1), 45-51$

e-ISSN: $2458-8377$

DOI:10.15316/SJAFS.2019.155

\title{
Determination of Population Development and Infestation Rates of Codling Moth [Cydia pomonella (L.) (Lep.: Tortricidae)] in Apple Orchards in Konya Province
}

\author{
Dilek AYDOĞAN ${ }^{1}$, Levent ÜNLÜ ${ }^{1, *}$ \\ ${ }^{1}$ Selçuk University, Faculty of Agriculture, Department of Plant Protection, Konya, Turkey
}

\begin{tabular}{l}
\hline ARTICLE INFO \\
\hline Article history: \\
Received date: 26.02 .2019 \\
Accepted date: 19.04 .2019 \\
\hline Edited by: \\
Murat KARACA; Selçuk University, \\
Turkey \\
Reviewed by: \\
Şenol YILDIZ; Bolu Abant İzet Baysal \\
University, Turkey \\
Mehmet MAMAY; Harran University, \\
Turkey \\
\hline Keywords: \\
Codling moth \\
Pheromone traps \\
Population \\
Infestation rate \\
Apple
\end{tabular}

\section{Introduction}

Apple is a commonly consumed fruit because of high antioxidant content and source of important nutrients and vitamins, as well as good taste. For this reason apple fruit is in demand at much higher than other temperate climate fruit species. Apple has found a wide range of ecological suitability of cultivation areas in Turkey. Most part of these produced apple fruits are consumed as a fresh in the local markets, and other parts used for fruit juice, fruit concentrate and so on as raw a material in industry (Taşc1, 2017).

The homeland of the apple extends to the South Caucasus, including Anatolia, among temperate climate fruit species and the culture dates back to the early centuries. Apple, which has the ability to adapt to different ecologies, showed a wide spread in the world. Today, apple production accounts for approximately $12 \%$ of the total fruit production in the world, and gets second place after banana (Taşc1, 2017).

\footnotetext{
*Corresponding author email : ulevent@ selcuk.edu.tr
}

Turkey is one of the most important apple producer countries in the world. Although the place in the ranking varies from year to year, Turkey finds its place among the top five countries in the world in terms of apple production area and amount. Apple production area in Turkey was 173.393,5 ha in 2018, from which Nigde Province took first place with its 23.409 ha, Isparta province took second place with 22.813 ha and Karaman District took third place with 19.556 ha area of production (TUIK, 2018).

Controlling diseases and pests is one of the main important problems during fruit growing. Among apple pests, codling moth has great importance for apple trees. Its larvae damage directly occurs on fruits, and larvae make galleries in the fruit through mesocarp and seeds. The wounds caused by codling moth lead to fruit rot. Thus, infested fruits fall to the ground; if the fruits can remain hung on the trees they lost the quality and quantity, therefore, the value of fruits in the market decreases. The damage of this pest may reach up to $60 \%$ or even $100 \%$ without controlling actions. Codling moth distributed in all apple growing areas in Turkey (Anonymous, 1995). 
Codling moth control methods mostly based on chemical control such as using wide spectrum insecticides, in the world as well as in Turkey. But recent studies have focused on biological and biotechnical control methods due to the known negative effects of chemical insecticides (Bulut and Kılınçer 1989). Sexual attraction pheromone traps are one of the methods of biotechnical control and have used mostly for monitoring specific pest species. These traps are used against many pest species around the world and in Turkey (Önder, 1987; Layık and Kısmalı, 1994; Hepdurgun et al., 1996; Kılıç et al., 1999; Kutinkova et al., 2009; Knight, 2010; Kakar et al., 2015).

When researches are examined from the open access literature on this topic, Cydia pomonella population development have been studied in Eğirdir district by İşci (2008), in Şanlıurfa province by Mamay and Yanık (2013), in Elazı̆̆ province by Ayaz and Yücel (2010) and in Beyşehir (Konya) district by Çelik ve Ünlü (2017) in apple orchards. Hantaş et al. (2014), also tested pheromone traps against codling moth in quince orchard in Marmara region.

The aim of this study was to investigate adult popu-

Table 1

Characteristics of the apple orchards of the study site lation development, infestation rates and some other biological properties of codling moth in apple orchards in central districts of Konya province.

\section{Materials and Methods}

The basic materials of this research were apple orchards located in Selçuklu, Meram and Karatay districts in Konya province and codling moth population in these orchards. Delta type pheromone traps were used to determine population development of codling moth. In all traps, sticky trays were used for catching and counting and species specific pheromone capsule (1,5 mg E.E-8.10-dodecadien-1-ol) for attract codling moth males to the traps. All orchards coordinates were obtained using a GPS device.

\section{Selecting Trial Orchards}

Two apple orchards were selected from Selcuklu, Meram and Karatay districts representing three central districts of Konya province. All orchards were at least 0.5 hectare in size and there was a interval of at least one kilometer between each orchards.

\begin{tabular}{|c|c|c|c|}
\hline & & Size (ha) & Orchard Age \\
\hline \multirow{2}{*}{ Selçuklu } & Çaltı & 2 & 12 \\
\hline & Kampüs & 4 & 14 \\
\hline \multirow{2}{*}{ Meram } & Hatıp & 1.5 & 7 \\
\hline & Kozağaç & 5 & 8 \\
\hline \multirow{2}{*}{ Karatay } & Karaaslan1 & 5 & 17 \\
\hline & Karaaslan2 & 7 & 6 \\
\hline \multicolumn{4}{|c|}{$\begin{array}{l}\text { Determination of Codling Moth Population Develop- } \\
\text { ment }\end{array}$} \\
\hline \multicolumn{4}{|c|}{$\begin{array}{l}\text { Researches on to monitore } C \text {. pomonella adult pop- } \\
\text { ulation development and infestation rates carried out in } \\
\text { the same orchards in both } 2017 \text { and } 2018 \text { years, in } \\
\text { Selçuklu, Meram and Karatay districts. Two phero- } \\
\text { mone traps placed in each orchard on } 1 \text { May in } 2017 \\
\text { and } 8 \text { May in } 2018 \text { to monitor population development. } \\
\text { The traps were hung at } 1.5-2 \text { m high from the ground } \\
\text { in the south direction of the trees and in the direction of } \\
\text { the dominant wind. Trap visits were performed twice a } \\
\text { week until the first adult was captured, and once a } \\
\text { week after the first adult was captured, the number of } \\
\text { captured adults was recorded. The pheromone capsules } \\
\text { of the traps were replaced every six weeks and old } \\
\text { capsules were removed from the orchards. The sticky } \\
\text { trays in the traps were replaced with new ones as need- } \\
\text { ed depending on the loss of the adhesive layer. }\end{array}$} \\
\hline
\end{tabular}

Determination of Infestation Rates of Codling Moth 
In order to determine the population development of the codling moth, sexually attraction traps were hung in six different orchards in the first week of May when the average temperature reached $13^{\circ} \mathrm{C}$. Figure 1

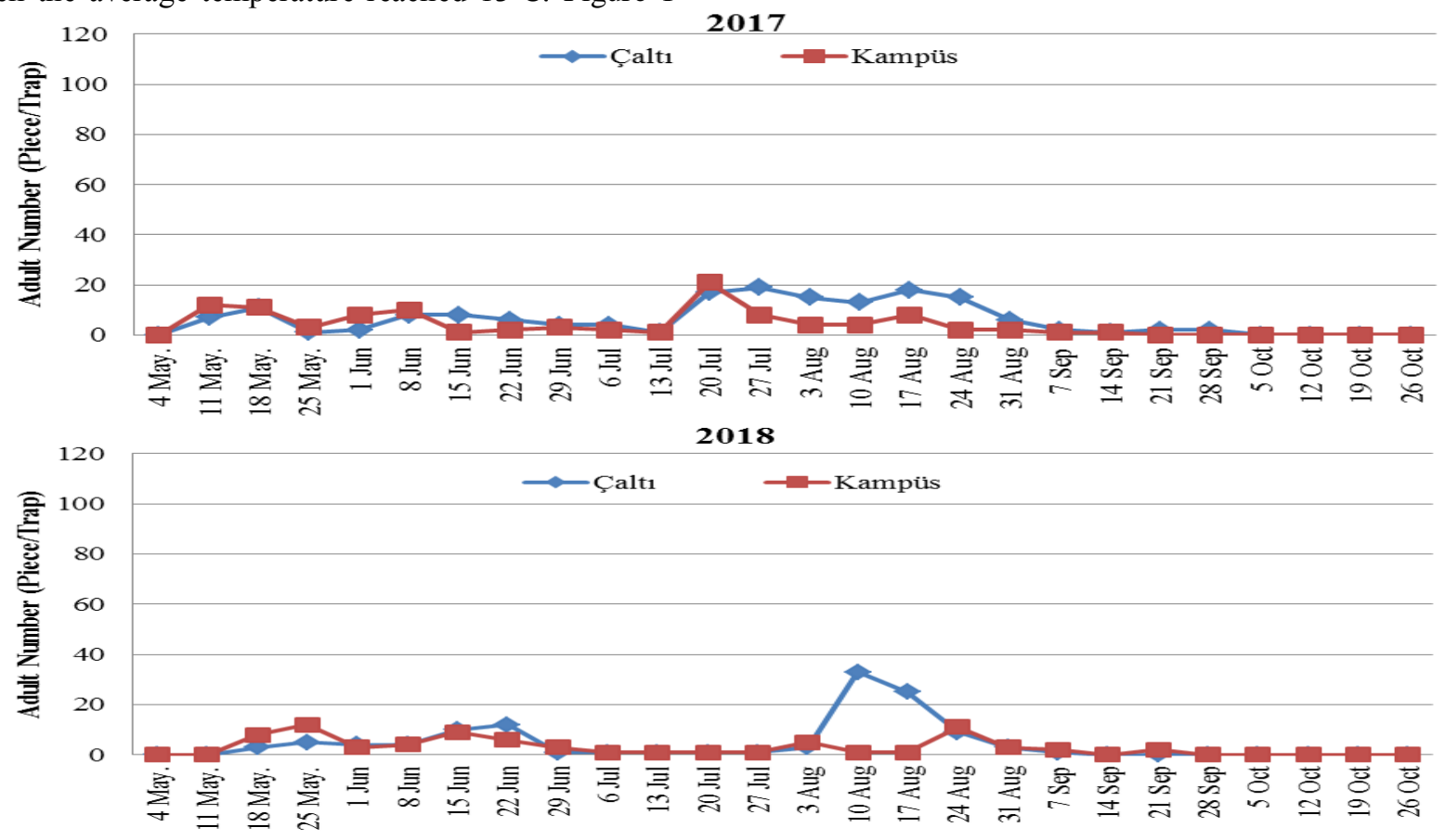

Figure 1

Population development of Cydia pomonella in Selcuklu in 2017-2018.

In 2017, the codling moth adults first captured by pheromone traps on 5 May in Çaltı. Codling moth formed four peaks in the season. The peak number of adults in pheromone traps, per week, was 11 on May 18, 8 on June 8,20 on July 27 and 18 on August 17. The last adults captured by traps were observed on September 28. In 2018, the codling moth adults first captured by traps on 11 May in Çalt1. The pest formed three peaks in the season. The peak number of adults in pheromone traps per week was 5 on May 25, 12 on June 22, 33 on August 10 (Figure 1).

Population development of Cydia pomonella in the campus orchard was shown in Figure 1. In 2017, Cydia pomonella adults first captured on 8 May and formed four peaks. The peak number of adults in pheromone traps per week was 12 on May 11, 10 on June 8, 21 on shows the development of adult population of the pest in Selçuklu district (Çaltı and Campus orchards) in 2017 and 2018.

2017 
2018

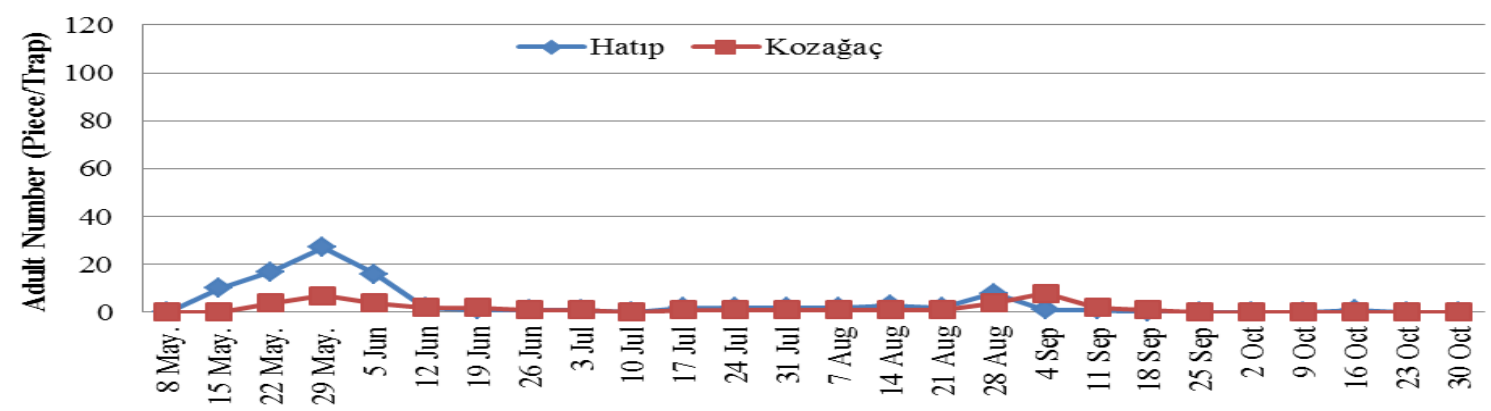

Figure 2(continuation)

Population development of Cydia pomonella in Meram in 2017-2018.

Cydia pomonella adults were first captured in the traps in Hatıp orchard on May 9 in 2017. The pest had four peaks in the season. The peak number of adults in traps per week was 68 on May 15, 36 on May 29, 68 on July 24 and 14 on September 11. However, in 2018 the first captures was detected on May 9, and peak number of adults in traps per week was 27 on May 29 and 8 on August 28, with two peak in the season.

In Kozağaç orchard, the first adults captured in the traps on May 9 in 2017. Codling moth had four peaks in the season. The peak number of adults in traps per week was 45 on May 15, 15 on July 24, 30 on August 14 and 23 on August 28. But in 2018, first adults cap- tured on May 16. The peak number of adults in traps per week was 7 on May 29 and 8 on September 4, with only two time peak in the season in Kozağaç orchard (Figure 2).

The first adult capture in traps was recorded in the second week of May in both orchards in Meram district in 2017 and 2018. The last capture of adults was recorded on October 16 in 2017, but in 2018, the last capture of adults was in Hatıp orchard on October 16 and in Kozağaç orchard on September 18.

Figure 3 shows population development of Cydia pomonella in Karatay district (Karaaslan 1 and Karaaslan 2 orchards) in 2017 and 2018.

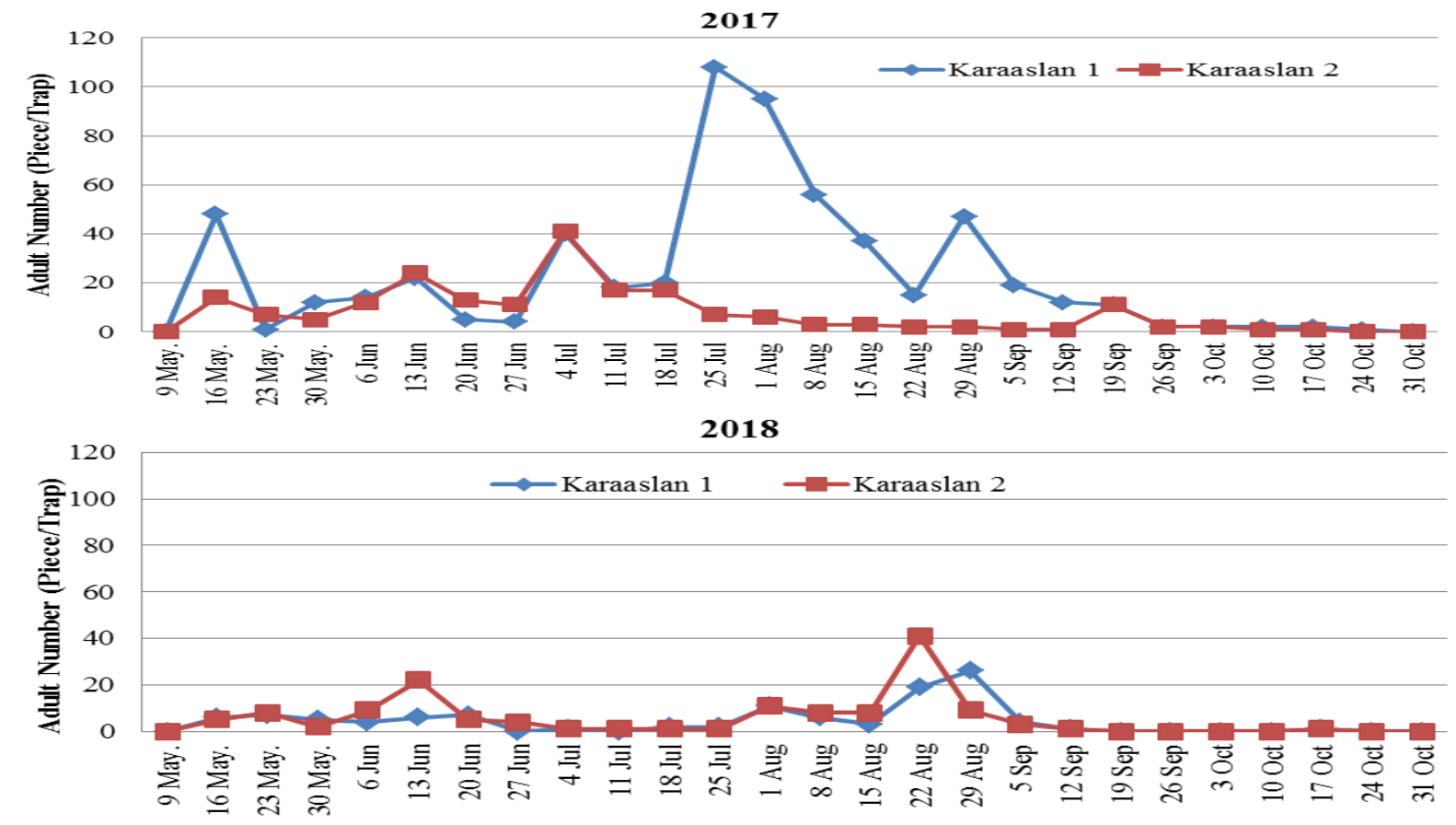

Figure 3

Population development of Cydia pomonella in Karatay in 2017-2018

In Karaaslan 1 orchard, the first adults captured in the traps on May 10 in 2017. Codling moth had four peaks in the season. The peak number of adults in traps rep week was 48 on May 16, 40 on July 4, 108 on July 25 and 47 on August 29. The last capture date was October 13. In 2018, first adults captured on May 12 in traps. The peak number of adults in traps per week was
7 on May 23, 7 on June 20, 11 on August 1 and 26 on August 29, with four peaks in the season (Figure 3).

In Karaaslan 2 orchard, adult moths were first captured in the traps on May 10 in 2017. The pest had four peaks in the season. The highest number of adults in traps per week was 16 on May 14, 24 on June 13, 41 on July 4 and 11 on September 19 . The last capture of adults was detected on October 17. In 2018, first adults 
captured on May 12 in traps. The peak number of adults in traps per week was 8 on May 23, 13 on June 22, 11 on August 1 and 41 on August 22, with four time peak in the season (Figure 3).

The first adult capture in traps was recorded in the second week of May in both orchards in Karatay district and the last capture of adults was recorded on October 17.

In the study, it was determined that codling moth has two-three generation per year. Also, it has been detected that population peaks was four times in 2017 and three times in 2018. The first emergence of the Cydia pomonella adults was seen in mid-May and was active for five months in nature. Özbek et al. (1995), has been reported that codling moth is the most important apple pests and has two-three generation per year depending to the region in our country. Aydar et al. (2007), has been stated that population densities of codling moth were very high in Eğirdir (Isparta) district. Ayaz and Yücel (2010) also noted codling moth first emergence on May 10 in Elazığ province.
Mamay and Yanik (2013) determined adult population of codling moth in Şanliurfa province. According to their results codling moth has three generation and four evident peaks (May, June, July and September) in the season and its active flight period in nature was determined for at least five months. Çelik and Ünlü (2017) also reported two-three generation and two and three population peaks of codling moth depending on the climate conditions in Beyşehir (Konya) district. Hantaş et al. (2014) stated that codling moth first emergence was seen on April 21 and produced four generations in the season in quince orchard.

\section{Infestation Rates of Codling Moth}

It is also important to estimate the infestation rate to determine the damage caused by the codling moth in the orchards. The infestation ratio of the codling moth in apples fruits indicates the financial loss of producers. Infestation rates of Cydia pomonella in 2017-2018 years is given in Table 2.

Table 2

Cydia pomonella infestation rate in Konya in 2017-2018 (\%)

\begin{tabular}{ccccccr}
\hline & \multicolumn{2}{c}{ Selçuklu } & \multicolumn{2}{c}{ Meram } & \multicolumn{2}{c}{ Karatay } \\
\hline Years & Kampüs & Çaltı & Hatıp & Kozağaç & Karaaslan 1 & Karaaslan 2 \\
\hline 2017 & 10.50 & 6.25 & 36.10 & 6.50 & 36.10 & 4.90 \\
2018 & 18.90 & 14.00 & 35.10 & 25.20 & 20.30 & 13.60 \\
\hline
\end{tabular}

In 2017, in the Campus orchard, the infestation rates changed between $7 \%$ and $16 \%$ throughout the year and the average was $10.5 \%$. While the infestation rate in Çaltı was low, apples were harvested from September 7 due to the damage of the hail on the apples in the orchard by $90 \%$. In 2018, in the campus orchard $C$. pomonella's infestation in fruits was $10 \%$ in July and increased gradually to $27 \%$ by the end of September. The average number of infestations in fruits was 18.9\%. In Çaltı, infestation rate was $14 \%$ in 2018.

In 2017 , the rate of infestation in fruits was found to be $36.1 \%$ in Hatıp orchard and $5 \%$ on August and $9 \%$ on September in Kozağaç orchard. Infestation rate in Karaaslan 1, which had higher in population density compared to other orchards, was found as $36.1 \%$ in 2017 and in Karaaslan 2, which had low in population density compared to other orchards, was found as $4.9 \%$.

In 2018, there was no significant change in terms of infestation level compared to the previous year in Hatıp orchard and the infestation rate was $35.1 \%$. In Kozağaç orchard, whilst low population density infestation rate was high as $25.2 \%$ in 2018. Infestation rate increased after mid-August in Karaaslan 1 orchard and was $20.3 \%$ in 2018. Karaaslan 2 orchard infestation rate was $13.6 \%$ and increased comparing previous year in 2018.

It was determined that the second generation in late August has more effect on infesting fruits by looking at the population density and infestation rates determined in the study.

In 2017, the population of the pest in Campus orchard was higher comparing to 2018 , however, the rate of infestation was higher in 2018, the first year of the study there was spraying at the visit date by the Ministry of Agriculture. In the second year, no spraying was carried out.

Population density of the pest in Çaltı orchard was higher in 2017 than 2018. However, in 2017 the economic value of apple fruits was very low due to the hail damage and early harvest. In 2018, five days after the warning dates of the agricultural district directorate were applied. Despite, five time insecticides has been applied during the season, but rate of infestation is still high, this may be due to the use of the same insecticides for six years. It can be guessed that the pest has developed resistance against this active ingredient.

In Hatıp orchard, insecticides applied twice in 2017 , but after spraying there was rainfall and the producer did not apply any more spraying after rainfall. In 2018 no spraying was carried out. This indicated that the farmer had experience that a very high financial loss when the insecticides was not applied against codling moth. Spraying five times in 2017 has increased considerably the chance of success against the pest in Kozağaç and infestation level was $6.5 \%$. But, in 2018 there was no spraying and because of this infesta- 
tion level was $25.2 \%$. This indicates importance of spraying on time against codling moth.

In Karaaslan 1, without spraying in 2017 in the orchard the infestation rate was $36.1 \%$, but in 2018 , the infestation rate has little decreased due to spraying two times. But spraying dates was randomly on June 17 and July 27. In Karaaslan 2, four times spraying carried out in the orchard and farmer considered to the time of spraying. Therefore, the least infestation in Karaaslan 2 orchard compared to other orchards, indicating that it is necessary to apply spraying according to the time of control.

For the year 2018, three sprayings were carried out according to the ministry of agriculture stated spraying times. However, the fourth treatment, which was not carried out in August, indicated that the infestation rate of the codling moth increased.

In the study, it was observed that the infestation rate of codling moth in apple orchards in the Selçuklu, Meram and Karatay districts of Konya province changed between 5-40\% in the first observation and in September it was seen between $4-43 \%$ in 2017. In the second year of the study, infestation rate was between $5-25 \%$ in July and $19-51 \%$ in October. Çelik and Ünlü (2017) reported infestation rates from orchard in Beyşehir (Konya) district in 2014-2015 year, which were $4-5 \%$ at the beginning of the first year and increased to $26-27 \%$ at the end of August, while in the second year adult numbers were between $4-7 \%$.

During the study it was noticed that the reason for the increase of infestation rate in late season was caused by the second generation of codling moth. Isci (2008), stated that the early apple varieties affected only by the first generation of pest, remaining $35-50 \%$ infestation, and the mid-late or late apple varieties affected more by the second generation of pest and damage increased to $80 \%$, with the advance of the harvest timefrom the apple orchard in Eğirdir Horticultural Research Institute,. Özbek et al. (1995), reported that, codling moth damage might reach up to $100 \%$ in some years and codling moth choose as a host not only apple, but quince, peach, walnut, plum, pear and apricot trees. Aydar et al. (2007) reported that the infestation rate was reached to $74.15 \%$ in the control plot without chemical application in Eğirdir (Isparta) district conditions. Kuyulu and Genç (2018), found the level of codling moth infestation between $5 \%$ and $95 \%$, in their study on the spread of codling moth in apple orchards in Çanakkale province

\section{Conclusion}

In this study, which aimed to determine codling moth population development and infestation rates in apple orchards in Selçuklu, Meram and Karatay districts of Konya province, it was found that codling moth emerged in the second week of May. The population peaks of codling moth were three-four times in the season depending on the weather conditions. Based on the result of this study, we state that codling moth can produce two-three generation per year depending on climatic conditions of the season. Codling moth started to emerge and captured in traps from the second week of May and this continued until the end of October. Therefore, codling moth has active flight period for five months in a year in central districts condition of Konya province.

With increasing temperatures, the population of codling moth reaches its peak in July-August. In this month, due to the rising population, the rate of infestation was increased towards the end of the season. In the apple orchards where the study was conducted, the average infestation was in 2017 and 2018 in Selçuklu $10.5 \%$ and $16.45 \%$; in Meram $21.3 \%$ and $30.15 \%$; and in Karatay $20.5 \%$ and $33.9 \%$, respectively.

In some orchards in which the study was carried out, no spraying was applied and in others the lack of spraying at the appropriate time caused the infestation level to occur high. It was observed that the chemical application against the codling moth is very important and the application should be applied on time.

The establishment of pheromone traps for codling moth at the beginning of May will ensure both the decreasing of the pest population density and the determination of the spraying times in Konya province conditions. It is known how important the timing of spraying is and how important to use pheromone traps because the pest enters into the fruits in a short time after the egg hatching.

For a long time, farmers couldn't obtain effective results with the chemical control because of random time of insecticides application. Appropriate time of spraying economically will remove a significant load from the farmers if they apply according to the changes in the population of the codling moth. It also helps to success spraying against codling moth. For this reason, it is important for farmers to apply sprayings properly announcements by official institutions.

\section{Acknowledgements}

This study is summarized from Dilek AYDOĞAN's Master's thesis. Authors are grateful to Tair Esenali UULU (PhD student, Department of Plant Protection, Faculty of Agriculture, Selcuk University) for translation help of manuscript. We would also like to thank Selcuk University Scientific Research Coordinator for their financial support (Project Number: 18201049).

\section{References}

Anonymous (1995). Zirai Mücadele Teknik Talimatları, Cilt:3. Tarım ve Köyişleri Bakanlığı, Koruma Kontrol Genel Müdürlüğü, Ankara. 445 s.

Ayaz T, Yücel A (2010). Elazığ İli Elma Alanlarında Bulunan Zararlı ve Yararlı Arthropod Türlerinin 
Belirlenmesi Üzerine Araştırmalar, HR.Ü.Z.F.Der., 14(1): 9-16

Aydar A, Zeki C, Sabahoğlu Y, Atlamaz A, Uzunok S, İşci M (2007). Elma Bahçelerinde Elma İçkurdu [Cydia pomonella (L.)] ve Elma Karalekesi Hastalığı [Venturia inaequalis (Cke.) Wint.]'nın Mücadelesinde Yardımcı Hava Akımlı Hidrolik Bahçe Pülverizatörünün Biyolojik Performansının Belirlenmesi. Tarım ve Köyişleri Bakanlığı TAGEM. Proje No: BS-04/08-05-121 (Sonuç raporu)

Bulut H, Kılınçer N, (1989). Elma İçkurdu \{Cydia pomonella L.)'nun Yumurta Parazitoidleri Trichogramma embryophagum Hartig), T. kilinceri Kostadinov ve Bunların Doğal Etkinlikleri Üzerinde Araştırmalar. Bitki Koruma Bülteni, 29(3-4): 165194.

Çelik H, Ünlü L (2017). Beyşehir (Konya) İlçesi Elma Bahçelerinde Elma İçkurdu Cydia pomonella (L.) (Lep.: Tortricidae)'nun Ergin Popülasyon Gelişimi ve Bulaşıklık Oranlarının Belirlenmesi, Harran Tarım ve Gıda Bilimleri Dergisi, 21(3): 266-278

Hantaş C, Çetin G, Akçay E (2014). Marmara Bölgesi Ayva Bahçelerinde Zararlı Böcek ve Akar Türleri ile Doğal Düşmanlarının Saptanması ve Önemli Zararlı Türlerin Popülasyon Değişimi, Bitki Koruma Bülteni, 54 (3):283-302

Hepdurgun B, Zümeroğlu A, Göker S, Hıncal P, Yaşarakıncı N (1996). Ege Bölgesi'nde Elma İçkurdu (Cydia pomonella (L.))'na Karşı Kitlesel Tuzaklama Yöntemi İle Mücadele Olanaklarının Araştırılması, 1996 Zirai Mücadele Araştırma Yıllığı, 5354.

İşci M (2008). Elma içkurdu Cydia pomonella (L.) (Lep.: Tortricidae)'nın farklı elma çeşitlerindeki zarar oranlarının belirlenmesi, Selçuk Üniversitesi Fen Bilimleri Enstitüsü, http://acikerisim.selcuk.edu.tr:8080/xmlui/handle/1 23456789

Kakar A, Anwar M, Kamran K, Iqbal F (2015). Chemical Control of Codling Moth, Cydia pomonella L. (Lep.: Tortricidae) in Relation to Pheromone Trap Catches and Degree Days in Upland Balochistan, Pakistan Journal of Zoology, 47 (2).

Kılıç M, Avcı Ü, Kahveci Y, Erdem B (1999). Karadeniz Bölgesi'nde Elma iç kurdu (Cydia pomonella
L.) (Lep.: Tortricidae)] mücadelesinde çiftleşmeyi engelleme yönteminin uygulanma olanakları üzerinde araştırmalar, Bitki Kor. Bül., 39: 45-55.

Knight AL (2010). Increased catch of female codling moth (Lep.: Tortricidae) in kairomone-baited clear delta traps, Environmental Entomology, 39 (2): 583- 590

Kutinkova H, Dzhuvinov V, Kostadinov R, Arnaudov V, Terziev I, Platon I, Rosu-Mares S (2009). Control of codling moth by "attract and kill" formulation in Bulgaria: 28 (4): 19-26.

Kuyulu A, Genç H (2018). Çanakkale İli Meyve Alanlarında Elma İçkurdu Cydia pomonella (L.) (Lepidoptera: Tortricidae)'nın Yayılışı Üzerine Bir Araştırma. Çanakkale Onsekiz Mart Üniversitesi, Ziraat Fak. Dergisi 2018: 6 (Özel Say1):85-91.

Layık FÖ, Kısmalı Ş (1994). Zararlılara karşı biyoteknik yöntemlerle savaşta kitle halinde tuzakla yakalama (mass-trapping) yönteminin kullanılması, Turkish Journal of Entomology, 18 (4).

Mamay M, Yanık E (2013). Şanlıurfa'da Elma Bahçelerinde Elma İçkurdu Cydia pomonella (L.) (Lep.: Tortricidae)'nın Populasyon Gelişimi ve Farklı Metotlar Kullanılarak Bulaşıklık Oranının Belirlenmesi, Tartm Bilimleri Derg., 19 (2): 113-120.

Önder PE (1987). Ege Bölgesi'nde Elma içkurduna karşı ilaçlı savaşımda tahmin ve uyarıya esas olarak eşeysel çekici tuzaklarla, etkili sıcaklık toplamlarından yararlanma olanakları, Türkiye I. Entomoloji Kongresi, 15-24s.

Özbek H, Güçlü Ş, Hayat R, Yıldırım E (1995). Meyve, Bağ ve Bazı Süs Bitkileri Zararlıları. Ata. Üni. Yay. No: 792, Ziraat Fak. Yayınları No:323. Erzurum. $357 \mathrm{~s}$.

Taşcı F (2017). Ürün Raporu Elma Tarımsal Ekonomi ve Politika Geliştirme Enstitüsü, Tepge Yayın No: 978-605-2207-01-7 ISBN: 296

TUIK (2018), https://biruni.tuik.gov.tr/medas/?kn=104\&locale=tr erişim tarihi 11.01.2018 